\title{
Revealing Microbial Population Complexity on Hospital Textiles Using DHPLC
}

\author{
Urška Rozman $^{1, *}$, Božena Kotnik Kevorkijan², Maja Rupnik ${ }^{3,4,5}$, Sonja Šostar Turk ${ }^{1,6}$ \\ ${ }^{1}$ Faculty of Health Sciences, University of Maribor, Žitna ulica 15, 2000 Maribor, Slovenia \\ ${ }^{2}$ Department of Infectious Disease and Febrile Conditions, University Medical Centre Maribor, \\ Ljubljanska ulica 5, 2000 Maribor, Slovenia \\ ${ }^{3}$ National Laboratory of Health, Environment and Food, Prvomajska ulica 1, 2000 Maribor, Slovenia \\ ${ }^{4}$ Center of Excellence for Integrated Approaches in Chemistry and Biology of Proteins, Jamova cesta 39, 1000 Ljubljana, Slovenia \\ ${ }^{5}$ Faculty of Medicine, University of Maribor, Taborska ulica 8, 2000 Maribor, Slovenia \\ ${ }^{6}$ Institute of Engineering Materials and Design, Faculty of Mechanical Engineering, University of Maribor, \\ I Smetanova ulica 17, 2000 Maribor, Slovenia
}

Copyright@2018 by authors, all rights reserved. Authors agree that this article remains permanently open access under the terms of the Creative Commons Attribution License 4.0 International License

\begin{abstract}
Hospital environment provides an important ecological niche that can serve as a reservoir for potentially pathogenic microorganisms. Hospital textiles together with moisture and heat create the right conditions for growth, dissemination and long-term survival of many microorganisms, which may results in transmission of nosocomial infections. Therefore, understanding of total microbial population on hospital textiles is an important part for assessment of public health risks. In the present work, we tested the suitability of DHPLC for estimation of total microbial population on hospital textiles. All of the identified bacteria belonged to the phyla Actinobacteria, Firmicutes and Proteobacteria and up to 63 bacterial genera/species were identified. Mostly abundant species important in perspective of HCAI were Acinetobacter spp., Corynebacterium spp., Staphylococcus spp., Sphingomonas mucosissima and Stenotrophomonas maltophilia. Microbial diversity on hospital textiles was extensive and partly coincides with the intensive care units bacterial communities and pathogens obtained from clinical samples. This is the first study describing total microbial population complexity on hospital textiles, which are important factors contributing to the hospital microbiome.
\end{abstract}

Keywords DHPLC, Healthcare Associated Infections, Hospital Environment, Hospital Textiles, Microbial Population

\section{Introduction}

Understanding microbial populations in hospital environments is crucial for improving human health [1], since indoor microbial communities are an important component of everyday human health [2,3]. Characteristics of the hospital environments are very specific where several major factors need to be considered: patients and medical workers, infections and resistant bacteria and also hospital inanimate environments including hospital textiles. Hospital textiles that come frequently into contact with hands are often contaminated with nosocomial pathogens and may serve as vectors for cross transmission and can be a source of healthcare associated infections [4]. Therefore, hospital textiles can contribute to the transmission of pathogens among hospital staff, patients and visitors. A single hand contact with contaminated textiles is enough to transfer the pathogens [5]. The patients are susceptible to colonization [6] and often underlying severe diseases [7,8] that can accelerate infection. Therefore, many patients get HCAI [healthcare associated infection] that implies in prolonged hospital stay, long-term disability, which are a massive additional financial burden for health systems, high costs for patients and their families, and excess deaths [9]. On the basis of the Report on the Burden of Endemic Health Care-Associated Infection Worldwide that included data from results of systematic reviews of the literature on endemic HCAI from 1995 to 2010 in high- and low/ middle-income countries is estimated that 4.131 .000 patients are affected by approximately 4.544 .100 episodes of HCAI every year in Europe. In Europe, HCAIs cause 16 million extra-days of hospital stay, 37.000 attributable deaths, and contribute to an additional 110.000 deaths every year. Annual financial losses are estimated at approximately $€ 7$ billion, including direct costs only. In the USA, approximately 99.000 deaths were attributed to HCAI in 2002 and the annual economic impact was 
estimated at approximately US\$ 6.5 billion in 2004 [9]. Another important fact regarding HCAI is increased resistance of microorganisms to antimicrobials. In hospital environments selective pressure for microorganisms is extreme and largely oriented for survival in hostile environments rather than for traits providing fitness in slowly evolving populations. Over the last century, the phenomenon of antibiotic resistant microorganisms that can survive in the presence of a broad spectrum of antimicrobial agents has developed [10]. The hospital environment may act as filter selecting specific bacterial populations and creating special and confined areas where microbiota clearly differs from that present in nature. Deep studies are needed to describe the microbial diversity associated to hospital environments to allow the identification of potential microorganisms causing HCAI [1].

For estimation of total microbial population complexity and studying of microbial diversity the microbial ecology has undergone a profound change in the last two decades. Emphasis has shifted from culturing to the molecular-based approaches [11] since most of the bacteria isolated from natural environments are not represented in culture collections [1]. On the other hand uncultured organisms comprise the vast majority of the microbial world [12-14], but most of the time encountered in complex environments [11] that also includes hospital environment. It is well known that cultivation-dependent techniques capture only a small part of the microbiome $[15,16]$ and that molecular methods can reveal high bacterial diversity [17], besides being faster and more reliable possibility. Although new generation sequencing techniques are currently becoming a standard for analysis of complex microbial populations, some older methods could still be used for populations with low or moderate complexity. One of such methods is denaturing high-performance liquid chromatography (DHPLC). DHPLC has been primarily used for mutation detection, mapping of genes, genotyping of known polymorphisms [18-21] and to detect DNA sequence variations such as insertions, deletions, genomic single nucleotide polymorphisms (SNPs), and microsatellites [22]. Limitations of DHPLC could be attributed to conserved nature of 16S rRNA genes, DNA extraction inherent limitations, formation of chimera and heteroduplex, preferential bias during the PCR [22] and the occurrence of mixed sequences in one fraction.

The aim of our survey was to test efficiency of the DHPLC method for the estimation of total microbial population of human pathogens on hospital textiles. We used a nondestructive sampling method that included a compact test device called Morapex A (SedoTreepoint $\mathrm{GmbH}$ ), which is based on forced desorption by pressing the microorganisms through the fabric, for nondestructive sampling the hospital textiles [23] and afterwards study microbial population complexity which is an important aspect in preventing nosocomial infections.

\section{Materials and Methods}

\subsection{Sampling}

To test the efficiency of a nondestructive elution method with the Morapex A device [23] two hospital sheets and one hospital pajama were sampled. Sheets and pajama were collected from patient at University Clinical Center Maribor at Department of Infectious Disease and Febrile Conditions in routine disposal of hospital laundry after being used for one day. Sheets were sampled at eight evenly spaced spots and pajama at three different spots (i.e. end of a sleeve, armpit and collar). The testing material was placed between two metal plates; $20 \mathrm{ml}$ test liquid $(0,9 \%$ $\mathrm{NaCl}+0,2 \%$ Tween 80 ) was pressed through the fabric in three cycles of 30 seconds and collected in a tube. The eluate was stored in a refrigerator until the DNA extraction. Sampling was conducted at room temperature.

\subsection{DNA Extraction}

Mixed bacterial genomic DNA was extracted from the suspension of microorganisms retrieved from textiles with a nondestructive the elution method described above. Extraction was performed with PrepMan Ultra Sample Preparation Reagent (Applied Biosystems) for each sampling spot on hospital textiles in accordance with the manufacturer's instructions. Extracted DNA was stored at $-20^{\circ} \mathrm{C}$ prior to $16 \mathrm{~s}$ rRNA gene amplification.

\subsection{S rRNA Gene Amplification}

The amplification of the targeted variable region V6 V8 of 16S rRNA gene was carried out with primers described by Domann et al. [24]. Forward primer 0933F (5'-GCACAAGCGGTGGAGCATGTGG - $3^{\prime}$ ) and the reverse primer 1407R (5'-GACGGGCGGTGTGTACAAG-3') were used. The amplicons obtained from mixed bacterial DNA were checked for the correct size [470 bp] by agarose gel electrophoresis. Heteroduplex DNA molecules were reduced by reconditioning as described by Thompson et al. [25]. Finally the PCR products were purified using the PCR Purification Kit from Qiagen.

\subsection{Separation of Amplified 16S rRNA Gene Fragments with DHPLC}

Purified PCR products were separated by DHPLC on a DNASep ${ }^{\circledR}$ HT cartridge using the WAVE Microbial Analysis System (Transgenomics, USA). For the particular analysis and separation of the mixed bacterial species we generated the gradient "mixed species" and used it at a 
column temperature of $62.0^{\circ} \mathrm{C}$ as described by Domann et al. [24]. The gradient was formed by buffer A, consisting of $0.1 \mathrm{M}$ triethylammonium acetate (TEAA), $\mathrm{pH} 7.0$, and buffer B, consisting of $0.1 \mathrm{M}$ TEAA and $25 \%$ acetonitrile, $\mathrm{pH}$ 7.0. Buffer C, consisting of $25 \%$ water and $75 \%$ acetonitrile, was used for washing the column [24]. Fractions representing chromatogram peaks were collected in different retention time intervals (Appendix). Percentage of representation in the sample was calculated based on area of each peak on DHPLC chromatogram [26].

\subsection{Sequencing of DHPLC Peaks and Cloning of Fraction}

From DHPLC chromatograms 188 most outstanding peaks were chosen and sent to Sanger sequencing at Macrogen (Netherlands). Nucleotide sequences were analyzed with the program RipSeq MIXED (Isentio). For fraction 7 in sample 8 cloning was performed using pGEM-T Vector System (Promega, Germany) for further identification. Altogether 28 cloned fragments were obtained and further analyzed in the WAVE system. Out of those, 12 that differed in retention times were selected, and processed for nucleotide sequences.

\subsection{Data Processing}

Data matrix based on the presence of the peak and the median value of retention time for each collected peak from DHPLC chromatograms was used as input for Principal Component Analysis (PCA). PCA cluster analytic method and visualization was performed with
Canoco and CanoDraw programs [27].

\section{Results}

Data analyzes described below are based on the chromatograms obtained by DHPLC method. Each point of the chromatogram was defined as the retention time (min) on the $\mathrm{x}$ axis and the signal intensity $(\mathrm{mV})$ on the $\mathrm{y}$-axis. One chromatogram represents one sampling spot on textiles from the hospital environment. Each chromatogram was composed of many peaks (Figure $1-3$ ), which differed by retention times and represented different taxa (Appendix).

From the different number of peaks per sample it can be seen that the complexity of the bacterial population varied between samples and that microbiota detected on sheet 1 and 2 was more complex in comparison to the pajama (Figure $1-3)$. On the other hand, the complexity of the bacterial population within single samples was quite similar, a certain deviation can be observed only in sample 6 from sheet 1 . Some of the peaks are attributed to several different taxa of bacteria, since the relatively short nucleotide sequences (420 bp), which was used for analysis by DHPLC did not allow precise identification of individual amplified fractions. In the case of mixed sequences the presence of three different bacterial genera/species in the samples was determined by RipSeq MIXED (Isentio) algorithm. Only sequences whose resemblance to a referenc sequence was higher than $99.5 \%$ were taken into account.

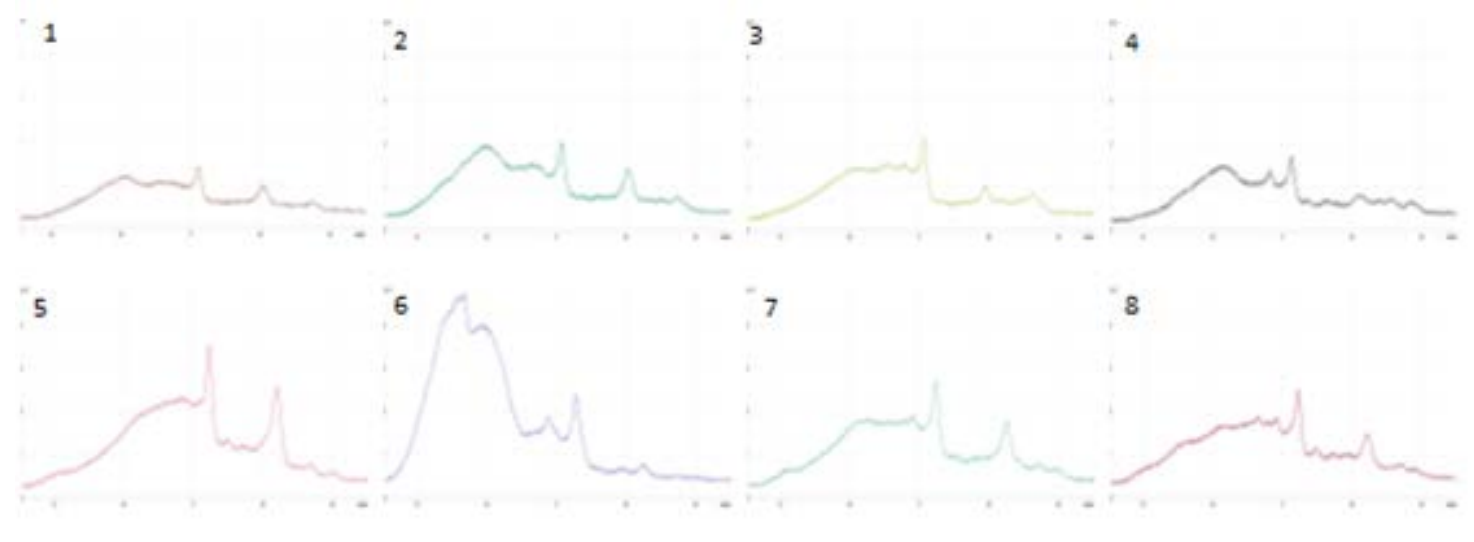

(a) 


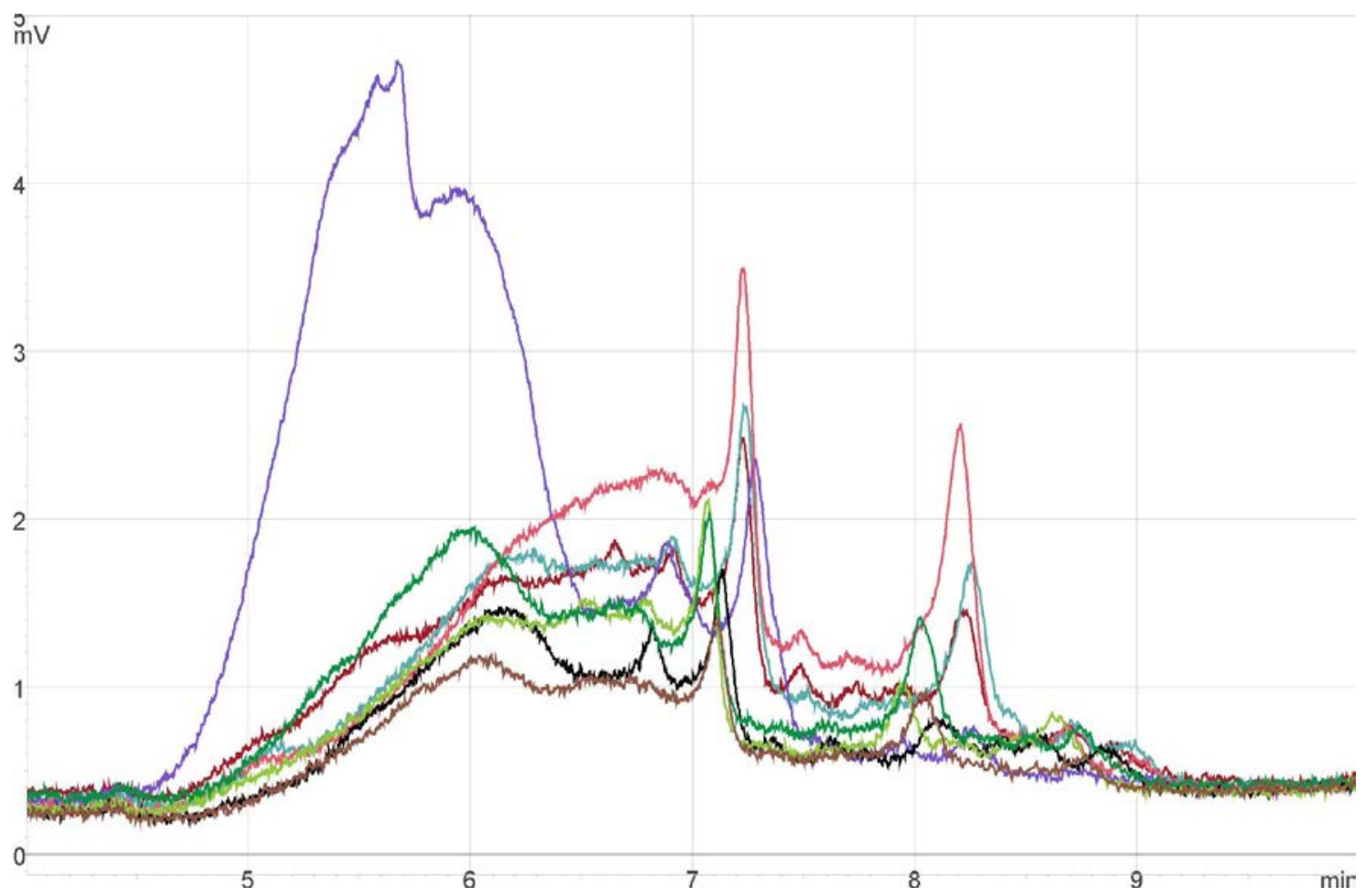

(b)

Figure 1. (a) DHPLC profiles of bacterial population on sheet 1: individual chromatograms for sampling spot 1 to 8 are represented in the small top figures. (b) The large bottom figure is the merged chromatograms from all eight sampling spots.

10

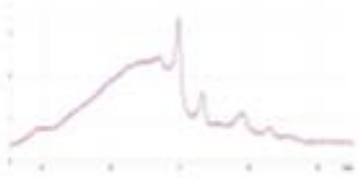

14
11

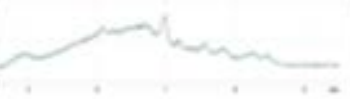

15

.

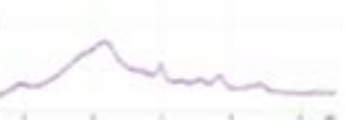

(a)
12

16

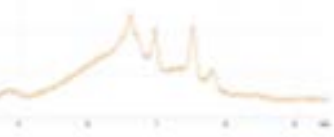




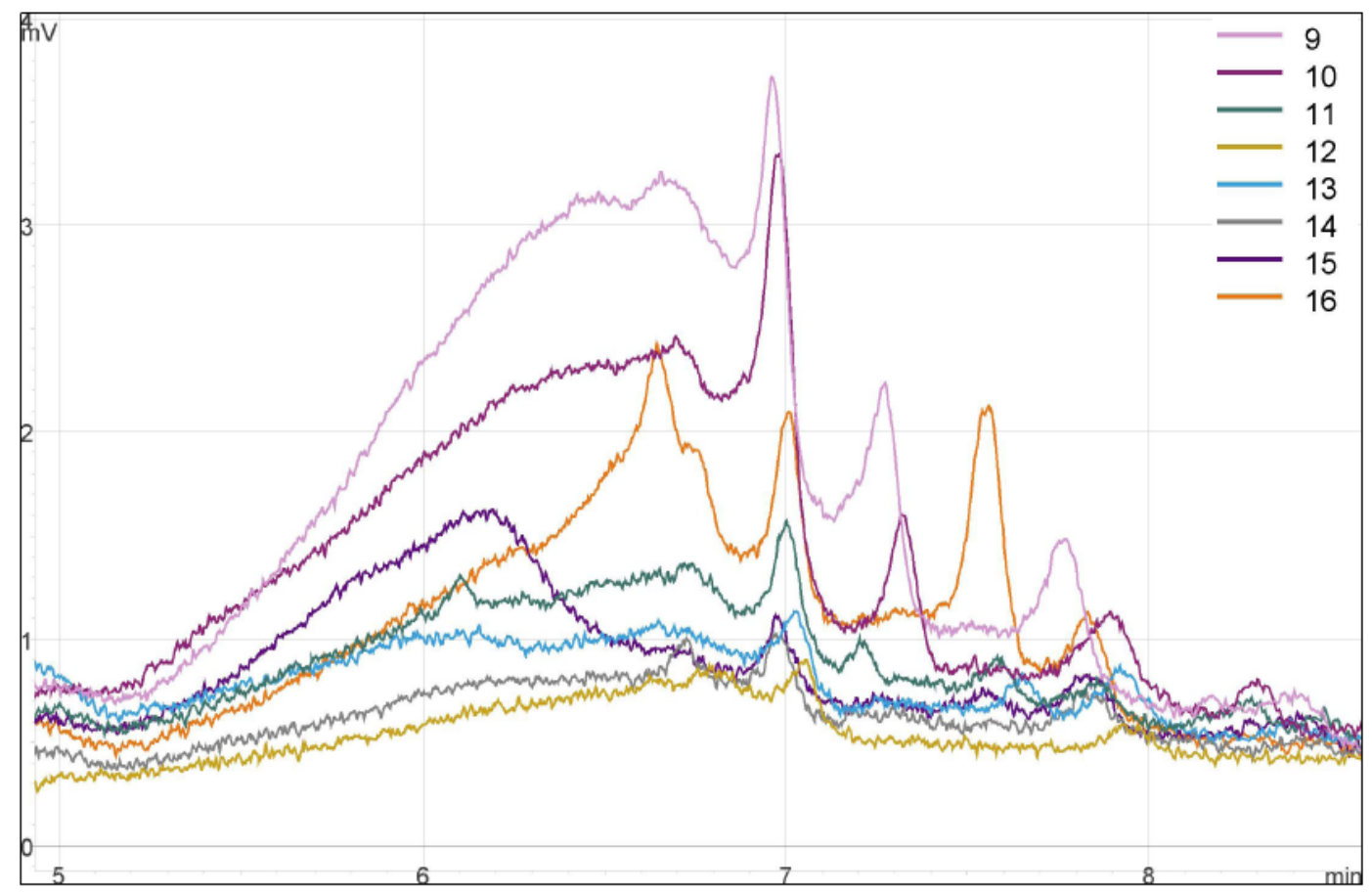

(b)

Figure 2. (a) DHPLC profiles of bacterial population on sheet 2: individual chromatograms for sampling spot 9 to 16 are represented in the small top figures. (b) The large bottom figure is the merged chromatograms from all eight sampling spots.

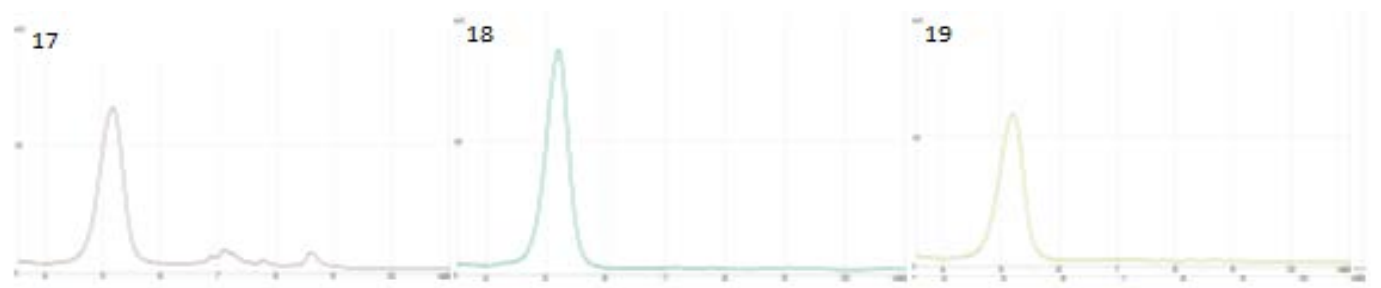

(a)

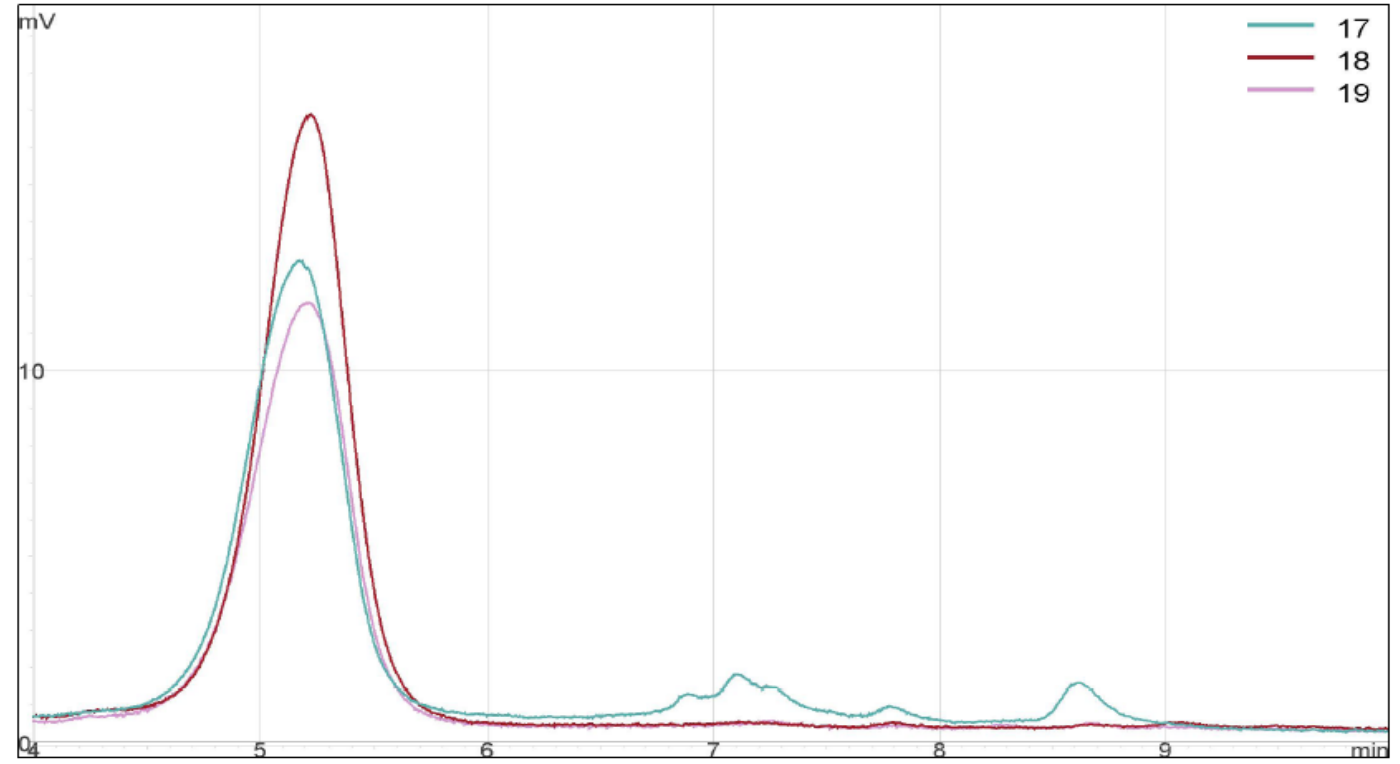

(b)

Figure 3. (a) DHPLC profiles of bacterial population on pajama: individual chromatograms for sampling spot 17 to 19 are represented in the small top figures. (b) The large bottom figure is the merged chromatograms from all three sampling spots. 
The composition of microbial populations included three bacterial phyla: Actinobacteria, Firmicutes and Proteobacteria. The phyla Actinobacteria was present at low levels and mainly represented by genus Corynebacterium spp. Second, regarding the percentage of representation was the phylum Firmicutes mainly represented by genus Bacillus spp., Enterococcus spp., Staphylococcus spp. and Streptococcus spp. The most abundant phylum across all samples (e.g. collected peaks) was Proteobacteria mainly represented by genus Cupriavidus spp., Ralstonia spp., Sphingomonas spp. and Stenotrophomonas spp.

On the sheet 1 a total of 59 different groups were identified, those were composed of various combinations of 56 bacterial genera/species (Appendix). The highest percentages among each of eight sampling spots on the sheet 1 are represented in Table 1 .

Table 1. Representation percentages of bacterial species on eight sampling spots of sheet 1

\begin{tabular}{|c|c|c|}
\hline $\begin{array}{c}\text { Sampling } \\
\text { spot }\end{array}$ & Bacterial species & $\begin{array}{l}\text { Percentage of } \\
\text { representation }\end{array}$ \\
\hline 1 & $\begin{array}{c}\text { Bordetella holmesii } \\
\text { Leptothrix spp }\end{array}$ & 21,3 \\
\hline 2 & $\begin{array}{l}\text { Ralstonia spp., } \\
\text { Sphingomonas } \\
\text { mucosissima } \\
\text { Stenotrophomonas } \\
\text { maltophilia } \\
\end{array}$ & 15,5 \\
\hline 3 & $\begin{array}{c}\text { Bordetella petrii } \\
\text { Cupriavidus spp. } \\
\text { Ralstonia spp. } \\
\text { Pandoraea sputorum } \\
\end{array}$ & 22,7 \\
\hline 4 & $\begin{array}{c}\text { Acinetobacter spp. } \\
\text { Moraxella osloensis } \\
\text { Shewanella putrefaciens } \\
\text { Acinetobacter baumannii } \\
\text { Acinetobacter junii } \\
\text { Stenotrophomonas } \\
\text { maltophilia }\end{array}$ & 23 \\
\hline 5 & $\begin{array}{c}\text { Paenalcaligenes hominis } \\
\text { Ralstonia spp. } \\
\text { Sutterella } \\
\text { wadsworthensis }\end{array}$ & 38,6 \\
\hline 6 & $\begin{array}{l}\text { Enterobacteriaceae } \\
\text { Proteus spp. } \\
\text { Yersinia spp. } \\
\text { Edwardsiella spp. }\end{array}$ & 28,3 \\
\hline 7 & $\begin{array}{c}\text { Ralstonia spp. } \\
\text { Pseudomonas spp. } \\
\text { Cupriavidus respiraculi } \\
\text { Sphingomonas } \\
\text { mucosissima }\end{array}$ & 79, 6 \\
\hline 8 & $\begin{array}{l}\text { Ralstonia spp. } \\
\text { Sphingomonas } \\
\text { mucosissima }\end{array}$ & 16 \\
\hline
\end{tabular}

The peak of the sample 6 (Figure 1) indicates the presence of bacteria from family Enterobacteriaceae.
On the sheet 2 a total of 50 different groups were identified, those were composed of various combinations of 63 bacterial genera/species (Appendix). The over represented groups reflected more than half of the bacterial population in the individual sampling spots. The highest percentages of representation among eight sampling spots on the sheet 2 are represented in Table 2.

Table 2. Representation percentages of bacterial species on eight sampling spots of sheet 2

\begin{tabular}{|c|c|c|}
\hline $\begin{array}{c}\text { Sampling } \\
\text { spot }\end{array}$ & Bacterial species & $\begin{array}{l}\text { Percentage of } \\
\text { representation }\end{array}$ \\
\hline 9 & $\begin{array}{c}\text { Cupriavidus respiraculi } \\
\text { Ralstonia spp. } \\
\text { Imtechium assamiensis } \\
\text { Sphingomonas mucosissima } \\
\text { Sphingomonas paucimobilis } \\
\text { Sphingomonas sanguinis } \\
\end{array}$ & 52,9 \\
\hline 10 & $\begin{array}{c}\text { Cupriavidus respiraculi } \\
\text { Ralstonia spp. } \\
\text { Paenalcaligenes hominis }\end{array}$ & 53,8 \\
\hline 11 & $\begin{array}{c}\text { Ralstonia spp. } \\
\text { Cupriavidus respiraculi } \\
\text { Corynebacterium accolens }\end{array}$ & 77,4 \\
\hline 12 & $\begin{array}{c}\text { Enterococcus spp. } \\
\text { Ralstonia spp. } \\
\text { Lactobacillus curvatus }\end{array}$ & 79,7 \\
\hline 13 & Kerstersia gyiorum & 35,5 \\
\hline 14 & Staphylococcus spp. & 44,5 \\
\hline 15 & $\begin{array}{c}\text { Acinetobacter baumannii } \\
\text { Acinetobacter junii } \\
\text { Bacillus circulans } \\
\text { Staphylococcus spp. }\end{array}$ & 62,9 \\
\hline 16 & $\begin{array}{c}\text { Corynebacterium spp. } \\
\text { Corynebacterium aurimucosum } \\
\text { Corynebacterium } \\
\text { tuberculostearicum } \\
\text { Corynebacterium freiburgense } \\
\text { Corynebacterium } \\
\text { tuberculostearicum } \\
\text { Sphingomonas sanguinis }\end{array}$ & 58,4 \\
\hline
\end{tabular}

On the pajama in all samples, the most outstanding peak appears at a retention time of 5,211 min. A total of 6 different groups were identified, those were composed of various combinations of five bacterial genera/species, but the highest percentage among three sampling spots where due to genus Staphylococcus spp. (93,8 \% on sampling spot 17), $100 \%$ of Staphylococcus spp. and Staphylococcus epidermidis (sampling spot 18) and again genus Staphylococcus spp. (99,9 \% on sampling spot 19).

The correlation between the bacterial community and environmental variables (pajama and sheets) was studied using Canoco. PCA using the entire retention time list clearly separated all identified species in four distinct clusters, visible in the 3-dimensional subspace spun by the first three principal components (Figure 4). 


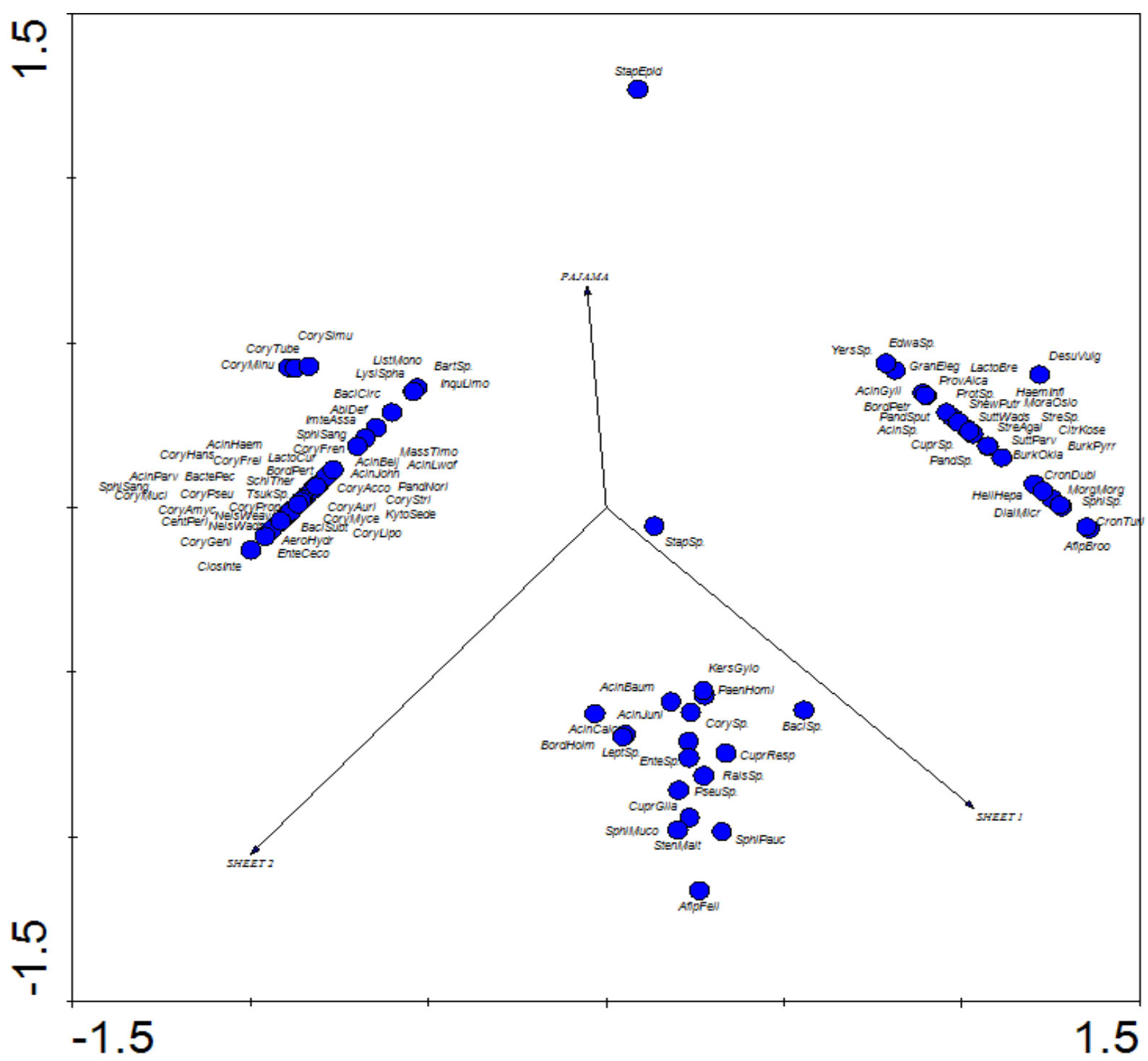

Figure 4. Principal components analysis from DHPLC data of the identified bacterial species showing bacterial community distribution among environmental variables (sheet 1 , sheet 2 and pajama)

Species S. epidermidis is clearly associated with the pajama cluster. At the bottom of the diagram there is a cluster of species Acinetobacter baumannii, Acinetobacter calcoaceticus, Acinetobacter junii, Afipia felis, Bacillus sp., Bordetella holmesii, Corynebacterium sp., Cupriavidus sp., Cupriavidus gilardii, Enterococcus sp., Kerstersia gyiorum, Leptothrix sp., Paenalcaligenes hominis, Pseudomonas sp., Ralstonia sp., Sphingomonas mucosissima, Sphingomonas paucimobilis and Stenotrophomonas maltophilia that were only abundant on sheet 1 or sheet 2. In the cluster of species oriented at the left side of the diagram, the dominant species are one from the genus Corynebacterium, while the cluster on the right side is very diverse. Close to the centre of diagram is Staphylococcus sp., indicating equal representation in all three samples.

\section{Discussion}

Different studies have been performed to describe microbial population in hospital environments (mostly intensive care units - ICU), but have been focusing on floors, medical devices, and workplaces $[1,17]$ and left out the hospital textiles as an important factor of the hospital's and the patient's environment. Phyla Actinobacteria, Firmicutes and Proteobacteria that were found in our study were also obtained for microbiota communities found in hospital ICU [1] and in the human body [28-30]. Also the finding in our study, that phylum Proteobacteria was most abundant, is consistent with finding of Obernauer et al. [17] in the ICU microbiome study.

According to a specialty of the Department of Infectious Disease and Febrile Conditions, which treated patients with severe, sometimes multiple infections and complications of infectious diseases as well as patients who require isolation, 
the high diversity of bacterial populations was expected. Regarding the percentage of the representation in the sampling spots at sheet 1 and sheet 2 the most common types, which are also important in terms of infections in humans and in terms of HCAI are the following: Acinetobacter baumannii, Acinetobacter junii, Bacillus circulans, Bordetella holmesii, Corynebacterium tuberculostearicum Edwardsiella spp., Pandoraea sputorum, Proteus spp., Sphingomonas mucosissima, Staphylococcus spp., Stenotrophomonas maltophilia, Sutterella wadsworthensis and Yersinia spp. Of the above-listed species on sheet 1 two types of bacteria were dominant. The first one is Sphingomonas mucosissima, for which there is a report on the cause of bacteremia, that's why it needs to be regarded as potentially pathogenic. Especially in impaired patients and patients undergoing medical procedures it could cause exceptional cases of opportunistic infections [31]. Sphingomonas members are metabolically versatile and its abundant presence in hospital textiles could be explained because this genus has a good ability to utilize a wide range of organic compounds and to grow and survive under low-nutrient conditions, including toxic compounds [32]. Actually S. paucimobilis has been previously detected in hospital equipment [33] and in respiratory therapy items, bedside water bottles, sinks etc. and has been described as a cause of minor infections in humans although it is also capable of causing serious infections [34]. The second one is Stenotrophomonas maltophilia, which is increasingly emerging as a cause of nosocomial infections, especially in immunocompromised patients, where the treatment of such infections can be problematic because of the resistance of different strains to many antibiotics [35]. On sheet 2 four types of the above-listed species were dominant. The first one is Corynebacterium spp. which is commonly present in humans but can also cause some diseases in both healthy and immunocompromised hosts [36]. The second one is Acinetobacter spp. that was also the dominant genus of the floor sample and present on almost all devices in ICU [17]. In aspect of nosocomial infections antibiotic-resistant Acinetobacter infections have become an increasingly common nosocomial problem $[37,38]$. The most important type is A. baumannii, which is resistant to a wide range of antibiotics [39]. The third and fourth outstanding species on sheet 2 were Sphingomonas mucosissima and Stenotrophomonas maltophilia described above.

Pajama is the part of the patient's environment that is in closest contact with the patient's skin; hence the microbial flora in pajama is quite different from that of the sheets. Highly over represented species are the one of the genus Staphylococcus spp. and species Staphylococcus aureus that can be found on human skin and mucosae and are therefore expected on samples that are in close skin contact. Obernauer et al. [17] describe Staphylococcus spp. as skin-associated genera that were highly abundant on medical devices and working surfaces, which are just like textiles touched by hands of hospital staff. Mentioned bacteria may induce a broad spectrum of infections in immunocompromised humans [40]. As an extremely versatile pathogen, this genus has developed a broad spectrum of mechanisms leading to resistance to our most powerful antimicrobial agents [1]. S. aureus is, in fact, one of the major causes of hospital acquired infection, being normal flora of ICUs [41] and as our results show, also normal flora of patient's pajama.

Textiles were partially colonized with human associated bacteria that were also found in other indoor microbial communities [3]. Species that have facultative pathogenic and nosocomial character, e.g. Pseudomonas spp., Haemophilus spp., Enterobacter spp., Citrobacter spp., Bordetella holmesii, Escherichia spp., Yersinia spp. and Proteus spp. are common pathogens obtained from clinical samples $[1,42,43]$ and were also present on textiles investigated in this study. This finding could classify hospital textiles as a part of environment where these pathogens are presumably existing, besides already recognized areas of colonization like mechanically controlled ventilation systems and catheters. Regarding issues in clinical settings Pseudomonas spp. find the hospital and intensive care unit environments accommodating and even more so hospital textiles as wet, body-temperature environment [44-46]. On the other hand families such as Corynebacteriaceae or Sphigomonadaceae do not usually cause infectious diseases therefore they do not appear in the clinical samples but are broadly overrepresented in ICU samples [1] and also in textiles samples from our study. Hospital bacterial communities are composed of bacteria closely related to human pathogens, but also of taxa known for their beneficial interaction with eukaryotes [17]. Therefore, whole bacteria community should be considered, since diversity within these communities often correlates with the ecosystem function of disease suppression [47].

Regarding the methodology some difficulties have emerged in the analysis of microbial populations on the hospital textiles by DHPLC. Identification to one bacterial species was not possible, and as a result there was only the probability of occurrence of up to three different bacterial genera/species, for which the percentage of representation cannot be determined. More accurate identification of individual fractions can be achieved with a shorter interval for collecting fractions on DHPLC chromatograms [48]. Škraban et al.[47] have collected fractions in $0.2 \mathrm{~min}$ interval and were successful in differentiation between selected groups in fecal specimens. Wagner et al. [26] have also been successful in distinguishing the individual fragments from DHPLC analysis of mixed microbial populations from complex environmental samples such as sludge, compost and soil. Since collecting fractions of distinct peaks did not yield satisfactory results in terms of separation, they have used cloning approaches. Similarly, in our study, we did in the repetition of sample 8 from sheet 
1. Our finding is that microbial diversity on hospital textiles is very extensive and partly coincides with the ICU bacterial communities from another study [1], but still the fact that DHPLC diversity profiles do not necessarily reflect the true diversity in the field [22] must be taken into account. The limitations could be attributed to different factors such as the conserved nature of 16S rRNA gene, DNA extraction inherent limitations and formation of chimera and heteroduplex. Closely similar DNA may result in clamping or clustering into a single or closely overlapping peak [22]. We believe that DHPLC can be used to monitor the diversity of microbial populations in a process, for example in the process of laundering hospital textiles or to compare the complexity of bacterial populations on textiles from different hospital departments. Similarly were the findings of Goldenberg et al. [49] that refer DHPLC as a suitable method for studying bacterial population dynamics in fermentation, bioremediation or environmental ecology [16]. Apart from that, Wagner et al. [26] describes the DHPLC method as suitable for a broad range of applications in microbial ecology. It is superior to other fingerprinting techniques in microbial ecology with easy application of conventional PCR, a high degree of automatization, and the possibility of quantifying fragments. A wide microbial diversity on hospital textiles described in this study points to the need for further research on microbial population's complexity on hospital textiles, since controlling the hygiene of hospital textiles is part of the surveillance programs for nosocomial infection prevention. Further research should especially be focusing on the possibility for transmission of pathogenic and multidrug resistant bacteria and virulent/resistant genes via contaminated textiles.

\section{Conclusions}

This study validates that DHPLC can be used to monitor the diversity of microbial populations on hospital textiles. Our research shows that the microbiota of hospital textiles is very complex and to some extent consistent with the microbiota of other hospital environments like devices, floor and workplaces. Therefore, hospital textiles are an important factor that contribute to the hospital microbiome and that should not be overlooked.

\section{Acknowledgements}

The research was funded by the Slovenian Research Agency ARRS (project No.1000-10-310152). We would also like to acknowledge Associate Professor Gregor Štiglic, PhD for his statistical assistance.

\section{Appendix: Identified Bacterial Species and their Representation in Each Sampling Spot on Sheet 1, Sheet 2 and Pajama. In Each Sampling Spot Fractions of Selected Chromatogram Peaks Were Analyzed}

\begin{tabular}{|c|c|c|c|}
\hline Fraction & Retention time & Genera / Species & $\begin{array}{c}\text { Representation } \\
\text { in sample [\%] }\end{array}$ \\
\hline \multicolumn{4}{|c|}{ SHEET 1} \\
\hline \multicolumn{4}{|c|}{ Sampling spot 1} \\
\hline \multirow{2}{*}{1} & 5,231 & Granulicatella elegans & \multirow{2}{*}{18,3} \\
\hline & 5,807 & Lactobacillus brevis & \\
\hline \multirow{2}{*}{2} & 5,831 & Bordetella holmesii & \multirow{2}{*}{21,3} \\
\hline & 6,298 & Leptothrix sp. & \\
\hline \multirow{3}{*}{3} & 6,327 & Kerstersia gyiorum & \multirow{3}{*}{17,1} \\
\hline & & Ralstonia sp. & \\
\hline & 6,644 & Streptococcus sp. & \\
\hline \multirow{2}{*}{4} & 6,701 & & \multirow{2}{*}{10,6} \\
\hline & 6,927 & Enterococcus sp. & \\
\hline \multirow{6}{*}{5} & 6,951 & Cupriavidus respiraculi & \multirow{6}{*}{10,4} \\
\hline & & Ralstonia sp. & \\
\hline & & Burkholderia oklahomensis & \\
\hline & & Burkholderia pyrrocinia & \\
\hline & & Pandoraea & \\
\hline & 7,231 & Sutterella parvirubra & \\
\hline \multirow{4}{*}{6} & 7,244 & Cupriavidus respiraculi & \multirow{4}{*}{4,5} \\
\hline & & Ralstonia sp. & \\
\hline & & Stenotrophomonas maltophilia & \\
\hline & 7,494 & Sphingomonas mucosissima & \\
\hline
\end{tabular}




\begin{tabular}{|c|c|c|c|}
\hline Fraction & Retention time & Genera / Species & $\begin{array}{l}\text { Representation } \\
\text { in sample [\%] }\end{array}$ \\
\hline \multirow{3}{*}{7} & 7,508 & Cupriavidus gilardii & \multirow{3}{*}{5,2} \\
\hline & & Sphingomonas mucosissima & \\
\hline & 7,784 & Stenotrophomonas maltophilia & \\
\hline \multirow{3}{*}{8} & 7,804 & Sphingomonas mucosissima & \multirow{3}{*}{11} \\
\hline & & Stenotrophomonas maltophilia & \\
\hline & 8,242 & Desulfovibrio vulgaris & \\
\hline \multirow{2}{*}{9} & 8,715 & Afipia broomeae / Afipia felis & \multirow{2}{*}{1,5} \\
\hline & 8,768 & Sphingomonas paucimobilis & \\
\hline \multicolumn{4}{|c|}{ Sampling spot 2} \\
\hline 5 & $\begin{array}{l}6,514 \\
6,668\end{array}$ & Ralstonia sp. & 6,8 \\
\hline \multirow{4}{*}{6} & 6,681 & Cupriavidus sp. / & \multirow{4}{*}{6,9} \\
\hline & & Ralstonia sp. & \\
\hline & & Enterococcus sp. & \\
\hline & 6,821 & Streptococcus agalactiae & \\
\hline \multirow{3}{*}{7} & 6,858 & Ralstonia sp. & \multirow{3}{*}{15,5} \\
\hline & & Sphingomonas mucosissima & \\
\hline & 7,251 & Stenotrophomonas maltophilia & \\
\hline \multirow{3}{*}{8} & 7,258 & Ralstonia sp. & \multirow{3}{*}{3,1} \\
\hline & & Sphingomonas mucosissima & \\
\hline & 7,481 & Stenotrophomonas maltophilia & \\
\hline \multirow{3}{*}{9} & 7,524 & Ralstonia sp. & \multirow{3}{*}{2,3} \\
\hline & & Sphingomonas mucosissima & \\
\hline & 7,687 & Stenotrophomonas maltophilia & \\
\hline \multirow{2}{*}{10} & 7,717 & Sphingomonas mucosissima & \multirow{7}{*}{11,1} \\
\hline & & Stenotrophomonas maltophilia & \\
\hline \multirow{2}{*}{11} & & Sphingomonas mucosissima & \\
\hline & & Stenotrophomonas maltophilia & \\
\hline \multirow{3}{*}{12} & & Sphingomonas sp. & \\
\hline & & Stenotrophomonas maltophilia & \\
\hline & 8,188 & & \\
\hline \multirow{3}{*}{13} & 8,742 & Afipia broomeae / Afipia felis & \multirow{3}{*}{1,2} \\
\hline & & Sphingomonas mucosissima & \\
\hline & 8,768 & Stenotrophomonas maltophilia & \\
\hline \multicolumn{4}{|c|}{ Sampling spot 3} \\
\hline \multirow{2}{*}{1} & 5,224 & Cupriavidus gilardii & \multirow{2}{*}{15,3} \\
\hline & 5,804 & Ralstonia sp. & \\
\hline & 5,824 & Bordetella petrii & \\
\hline 2 & & Cupriavidus sp. / Ralstonia sp. & 22,7 \\
\hline & 6,301 & Pandoraea sputorum & \\
\hline 3 & 6,344 & Ralstonia sp. & 10.2 \\
\hline 3 & 6,557 & Ralstonıa sp. & 10,2 \\
\hline 4 & 6,591 & Ralstonia sp. & 6.9 \\
\hline 4 & 6,698 & & \\
\hline 5 & 6,724 & Ralstonia sp. & 9,1 \\
\hline & 6,924 & & \\
\hline 6 & $\begin{array}{l}6,938 \\
7,071\end{array}$ & Ralstonia sp. & 13,9 \\
\hline
\end{tabular}




\begin{tabular}{|c|c|c|c|}
\hline Fraction & Retention time & Genera / Species & $\begin{array}{r}\text { Representation } \\
\text { in sample [\%] }\end{array}$ \\
\hline \multirow{3}{*}{7} & 7,191 & Helicobacter hepaticus & \multirow{3}{*}{5,5} \\
\hline & & Stenotrophomonas maltophilia & \\
\hline & 7,734 & Sphingomonas mucosissima & \\
\hline \multirow{3}{*}{8} & 7,764 & Helicobacter hepaticus & \multirow{3}{*}{6,5} \\
\hline & & Stenotrophomonas maltophilia & \\
\hline & 8,108 & Sphingomonas mucosissima & \\
\hline \multirow{3}{*}{9} & 8,142 & Helicobacter hepaticus & \multirow{3}{*}{2,3} \\
\hline & & Stenotrophomonas maltophilia & \\
\hline & 8,255 & Sphingomonas mucosissima & \\
\hline 10 & $\begin{array}{l}8,402 \\
8,742 \\
\end{array}$ & Sphingomonas paucimobilis & 7,5 \\
\hline \multicolumn{4}{|c|}{ Sampling spot 4} \\
\hline \multirow{2}{*}{1} & 5,284 & Acinetobacter calcoaceticus / Acinetobacter gyllenbergii & 7,2 \\
\hline & 5,621 & Moraxella osloensis & \\
\hline \multirow{3}{*}{2} & 5,637 & Acinetobacter sp. & \multirow{3}{*}{11,4} \\
\hline & & Moraxella osloensis & \\
\hline & 5,914 & Shewanella putrefaciens & \\
\hline \multirow{8}{*}{4} & 5,938 & Acinetobacter sp. & \multirow{8}{*}{23,5} \\
\hline & & Moraxella osloensis & \\
\hline & & Shewanella putrefaciens & \\
\hline & & Moraxella osloensis / & \\
\hline & & Acinetobacter baumannii & \\
\hline & & Acinetobacter junii & \\
\hline & & Stenotrophomonas maltophilia & \\
\hline & 6,311 & & \\
\hline \multirow[b]{2}{*}{5} & 6,394 & Acinetobacter sp. & \multirow[b]{2}{*}{11,2} \\
\hline & 6,628 & Ralstonia sp. & \\
\hline \multirow{3}{*}{6} & 6,651 & Pseudomonas sp. & \multirow{3}{*}{14,1} \\
\hline & & Ralstonia sp. & \\
\hline & 6,944 & Shewanella putrefaciens & \\
\hline \multirow{3}{*}{7} & 6,967 & Moraxella osloensis & \multirow{3}{*}{13,5} \\
\hline & & Acinetobacter sp. & \\
\hline & 7,251 & Stenotrophomonas maltophilia & \\
\hline \multirow[b]{2}{*}{8} & 7,267 & Sphingomonas paucimobilis & \multirow[b]{2}{*}{2,3} \\
\hline & 7,441 & Stenotrophomonas maltophilia & \\
\hline \multirow{3}{*}{9} & 7,577 & Bacillus sp. & \multirow{3}{*}{3,8} \\
\hline & & Sphingomonas paucimobilis & \\
\hline & 7,831 & Stenotrophomonas maltophilia & \\
\hline & 7,964 & Afipia felis & \\
\hline 10 & & Sphingomonas paucimobilis & 6,2 \\
\hline & 8,262 & Stenotrophomonas maltophilia & \\
\hline & 8,308 & Sphingomonas paucimobilis & \\
\hline 11 & 8,435 & Stenotrophomonas maltophilia & 2,1 \\
\hline & 8,468 & Cupriavidus gilardii / Cupriavidus respiraculi & \\
\hline 12 & 8,588 & Ralstonia sp. & 3,3 \\
\hline 13 & $\begin{array}{l}8,842 \\
8,895\end{array}$ & Ralstonia sp. & 1,5 \\
\hline
\end{tabular}




\begin{tabular}{|c|c|c|c|}
\hline Fraction & Retention time & Genera / Species & $\begin{array}{r}\text { Representation } \\
\text { in sample [\%] }\end{array}$ \\
\hline \multicolumn{4}{|c|}{ Sampling spot 5} \\
\hline \multirow{3}{*}{2} & 5,351 & Paenalcaligenes hominis & \multirow{3}{*}{38,6} \\
\hline & & Ralstonia sp. & \\
\hline & 6,614 & Sutterella wadsworthensis & \\
\hline \multirow[b]{2}{*}{3} & 6,634 & Ralstonia sp. & \multirow[b]{2}{*}{19,7} \\
\hline & & Sphingomonas mucosissima & \\
\hline \multirow[b]{2}{*}{4} & 7,051 & Ralstonia sp. & \multirow[b]{2}{*}{6} \\
\hline & 7,131 & Sphingomonas mucosissima & \\
\hline \multirow[b]{2}{*}{5} & 7,224 & Ralstonia sp. & \multirow[b]{2}{*}{7,7} \\
\hline & 7,374 & Sphingomonas mucosissima & \\
\hline \multirow{3}{*}{6} & 7,411 & Ralstonia sp. & \multirow{3}{*}{2,6} \\
\hline & & Sphingomonas mucosissima & \\
\hline & 7,491 & Stenotrophomonas maltophilia & \\
\hline \multirow{3}{*}{7} & 7,531 & 1 & \multirow{3}{*}{6,7} \\
\hline & & Sphingomonas mucosissima & \\
\hline & 7,867 & Stenotrophomonas maltophilia & \\
\hline \multirow{2}{*}{8} & 7,884 & Sphingomonas mucosissima & \multirow{2}{*}{2,5} \\
\hline & 7,977 & Stenotrophomonas maltophilia & \\
\hline \multirow[b]{2}{*}{9} & 8,015 & Sphingomonas mucosissima & \multirow[b]{2}{*}{16,3} \\
\hline & 8,675 & Stenotrophomonas maltophilia & \\
\hline \multicolumn{4}{|c|}{ Sampling spot 6} \\
\hline \multirow{3}{*}{1} & 4,707 & & \\
\hline & & Proteus sp. & \\
\hline & & Yersinia sp. & \\
\hline
\end{tabular}

2

5,414

5,424

3

5,641

5,674

5,787

\begin{tabular}{cl}
\hline 4 & 5,674 \\
& 5
\end{tabular}

6

6

7

\begin{tabular}{l}
7 \\
6,371 \\
\hline 6,514
\end{tabular}

8

7,097

7,111

9

7,714

7,741

10

8,095

11
Yersinia sp.

Edwardsiella sp.

Proteus sp.

17

Providencia alcalifaciens

Haemophilus influenzae

Cronobacter dublinensis

Citrobacter koseri

Cronobacter dublinensis

Proteus sp.

Corynebacterium sp.

Morganella morganii 


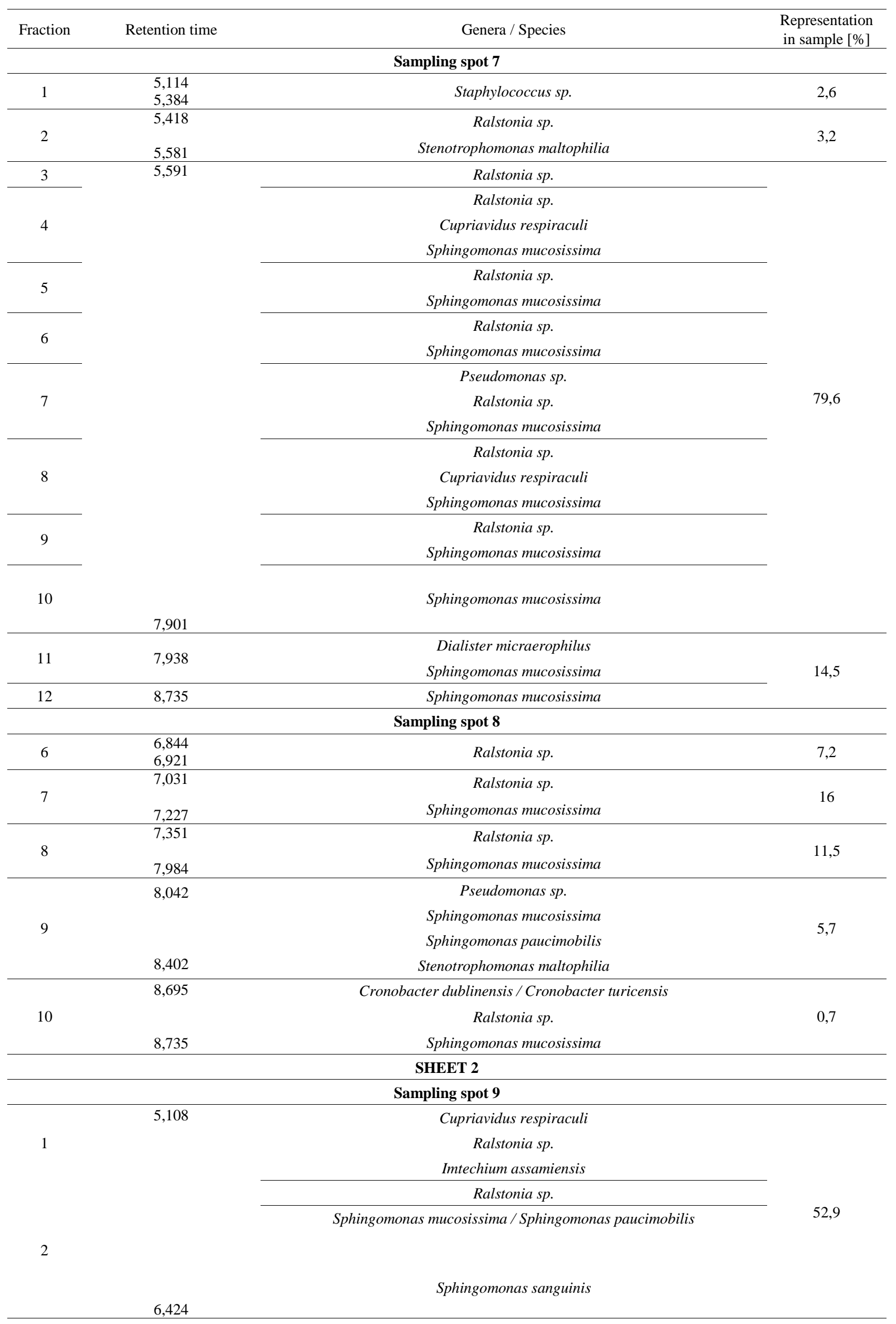




\begin{tabular}{|c|c|c|c|}
\hline Fraction & Retention time & Genera / Species & $\begin{array}{c}\text { Representation } \\
\text { in sample [\%] }\end{array}$ \\
\hline \multirow{5}{*}{3} & 6,477 & Corynebacterium tuberculostearicum & \multirow{5}{*}{10,9} \\
\hline & & Cupriavidus respiraculi & \\
\hline & & / & \\
\hline & & Imtechium assamiensis & \\
\hline & 6,731 & & \\
\hline \multirow{6}{*}{4} & 6,787 & Corynebacterium minutissimum & \multirow{6}{*}{15,1} \\
\hline & & Corynebacterium propinquum & \\
\hline & & Corynebacterium pseudodiphtheriticum & \\
\hline & & Cupriavidus respiraculi & \\
\hline & & Ralstonia sp. & \\
\hline & 7,008 & & \\
\hline \multirow{6}{*}{5} & 7,048 & Corynebacterium striatum / & \multirow{6}{*}{8,4} \\
\hline & & Corynebacterium tuberculostearicum & \\
\hline & & Cupriavidus gilardii & \\
\hline & & Ralstonia sp. & \\
\hline & & Sphingomonas mucosissima & \\
\hline & 7,291 & Sphingomonas mucosissima & \\
\hline 6 & 7,314 & Sphingomonas mucosissima / Sphingomonas paucimobilis & \multirow{4}{*}{9,2} \\
\hline \multirow{3}{*}{7} & & Bacillus subtilis / & \\
\hline & & Sphingomonas mucosissima & \\
\hline & 7,871 & Sphingomonas paucimobilis & \\
\hline \multirow{3}{*}{8} & 7,951 & Afipia felis & \multirow{3}{*}{0,8} \\
\hline & & Enterococcus cecorum & \\
\hline & 8,302 & Sphingomonas mucosissima & \\
\hline \multicolumn{4}{|c|}{ Sampling spot 10} \\
\hline \multirow{3}{*}{1} & 5,194 & Cupriavidus respiraculi & \multirow{4}{*}{53,8} \\
\hline & & Ralstonia sp. & \\
\hline & & Paenalcaligenes hominis & \\
\hline 2 & 6,511 & Ralstonia sp. & \\
\hline \multirow{3}{*}{3} & 6,537 & Corynebacterium freneyi / Corynebacterium hansenii & \multirow{3}{*}{16,2} \\
\hline & & Massilia timonae & \\
\hline & 6,827 & Ralstonia sp. & \\
\hline 4 & $\begin{array}{l}6,851 \\
7,168\end{array}$ & Ralstonia sp. & 10,6 \\
\hline \multirow{2}{*}{5} & 7,177 & Corynebacterium aurimucosum & \multirow{2}{*}{7,4} \\
\hline & 7,477 & Kytococcus sedentarius & \\
\hline \multicolumn{4}{|c|}{ Sampling spot 11} \\
\hline \multirow[b]{2}{*}{1} & 4,847 & Listeria monocytogenes & \multirow[b]{2}{*}{3,8} \\
\hline & 5,051 & Staphylococcus sp. & \\
\hline 3 & 5,221 & Ralstonia sp. & \multirow{7}{*}{77,4} \\
\hline \multirow{2}{*}{4} & & Cupriavidus respiraculi & \\
\hline & & Ralstonia sp. & \\
\hline 5 & & Ralstonia sp. & \\
\hline \multirow{2}{*}{6} & & Corynebacterium accolens & \\
\hline & & Ralstonia sp. & \\
\hline 7 & & Ralstonia sp. & \\
\hline
\end{tabular}




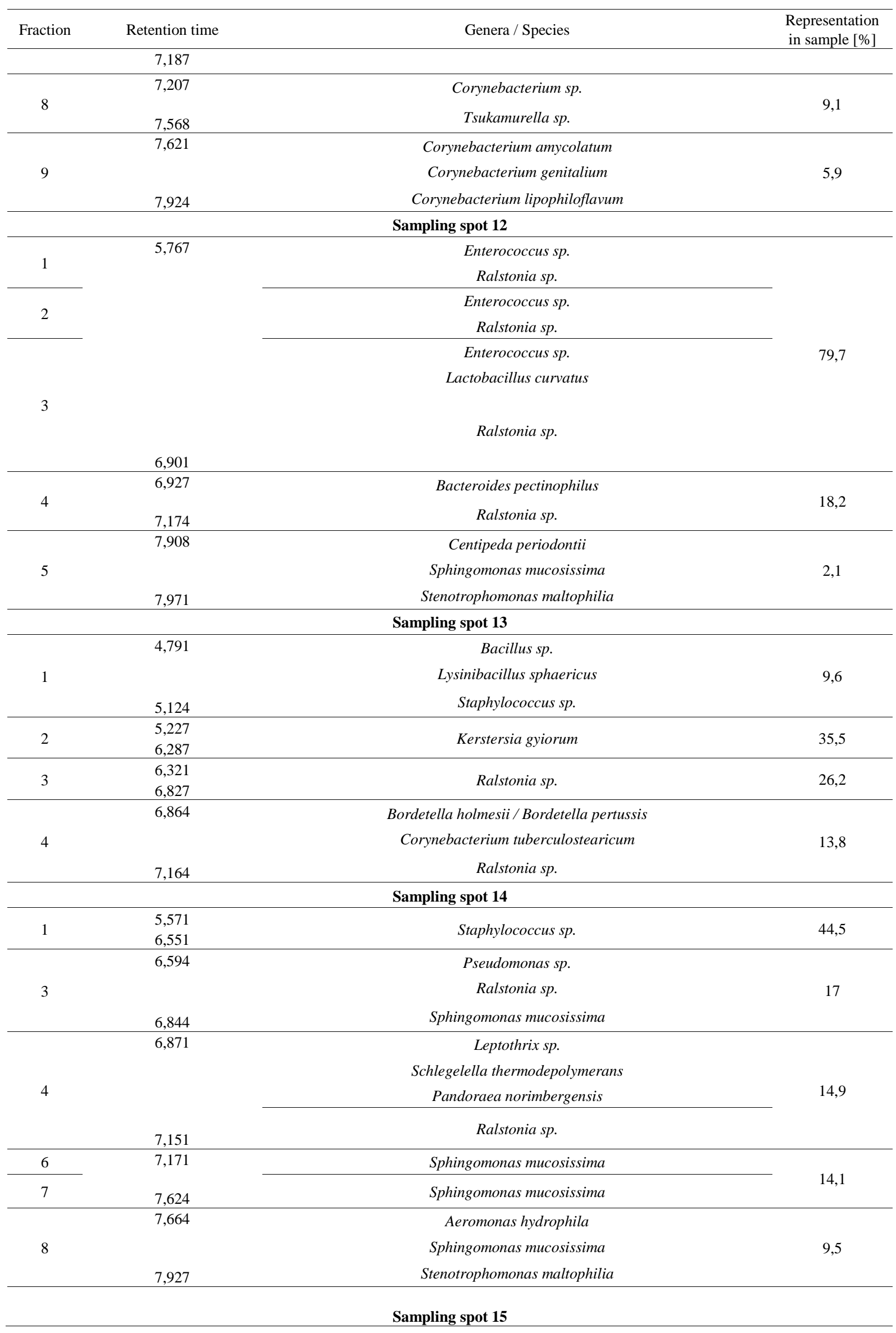




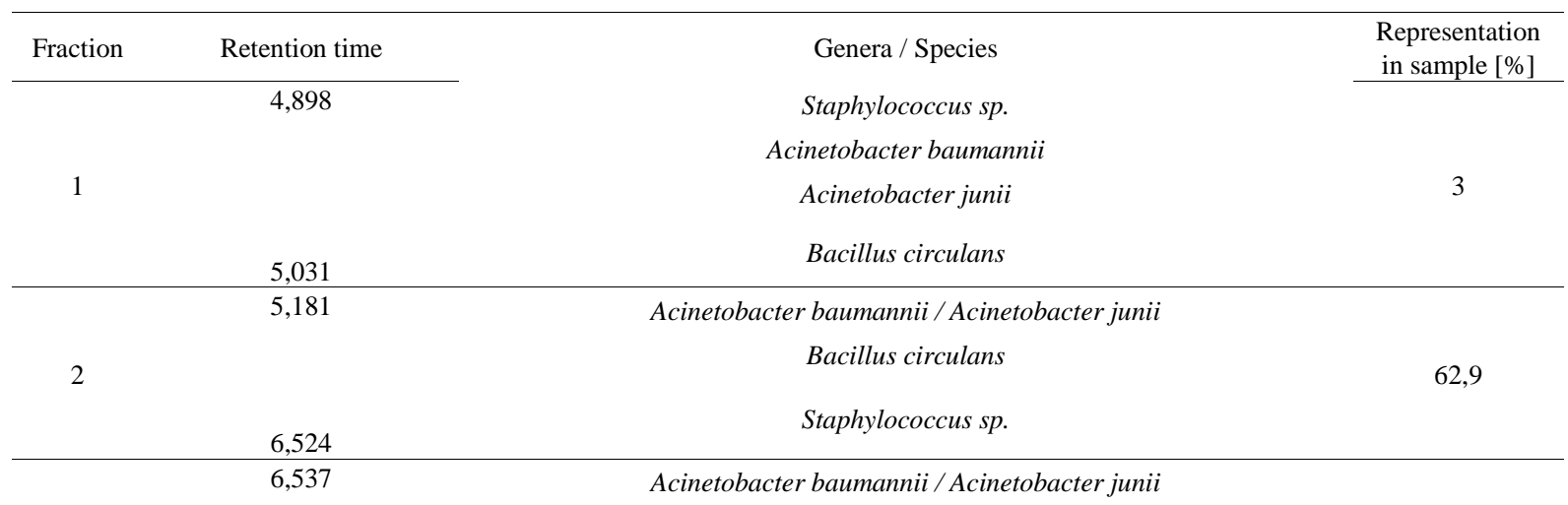

3 6,834

6,847

4 7,264

7,284

5

6

\begin{tabular}{cc} 
& 7,398 \\
\hline \multirow{2}{*}{7} & 7,408 \\
& 7,67 \\
\hline & 7,69
\end{tabular}

7,901

8,408

10 8,428

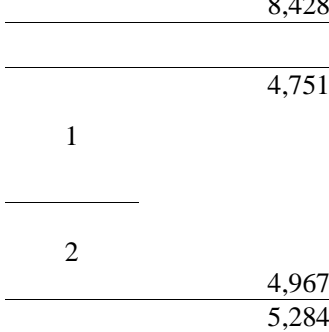

3 5,284

751
Acinetobacter beijerinckii / Acinetobacter haemolyticus / Acinetobacter johnsonii / Acinetobacter lwoffii Acinetobacter baumannii / Acinetobacter calcoaceticus / Acinetobacter junii / Acinetobacter parvus

Stenotrophomonas maltophilia

Corynebacterium sp.

Ralstonia sp.

Sphingomonas mucosissima

Sphingomonas sanguinis

Corynebacterium amycolatum

Sphingomonas mucosissima

Sphingomonas paucimobilis

Corynebacterium propinquum / Corynebacterium pseudodiphtheriticum

Sphingomonas mucosissima

Clostridium intestinale

Sphingomonas mucosissima

Sphingomonas sanguinis

Sampling spot 16

Bartonella sp.

Inquilinus limosus

Sphingomonas mucosissima

Abiotrophia defectiva

Staphylococcus sp.

Corynebacterium aurimucosum / Corynebacterium tuberculostearicum

Corynebacterium freiburgense

Corynebacterium freiburgense

Corynebacterium tuberculostearicum

Corynebacterium freiburgense

Corynebacterium tuberculostearicum

5

Sphingomonas sanguinis

6,821

$6-6,834$

Corynebacterium freiburgense / 


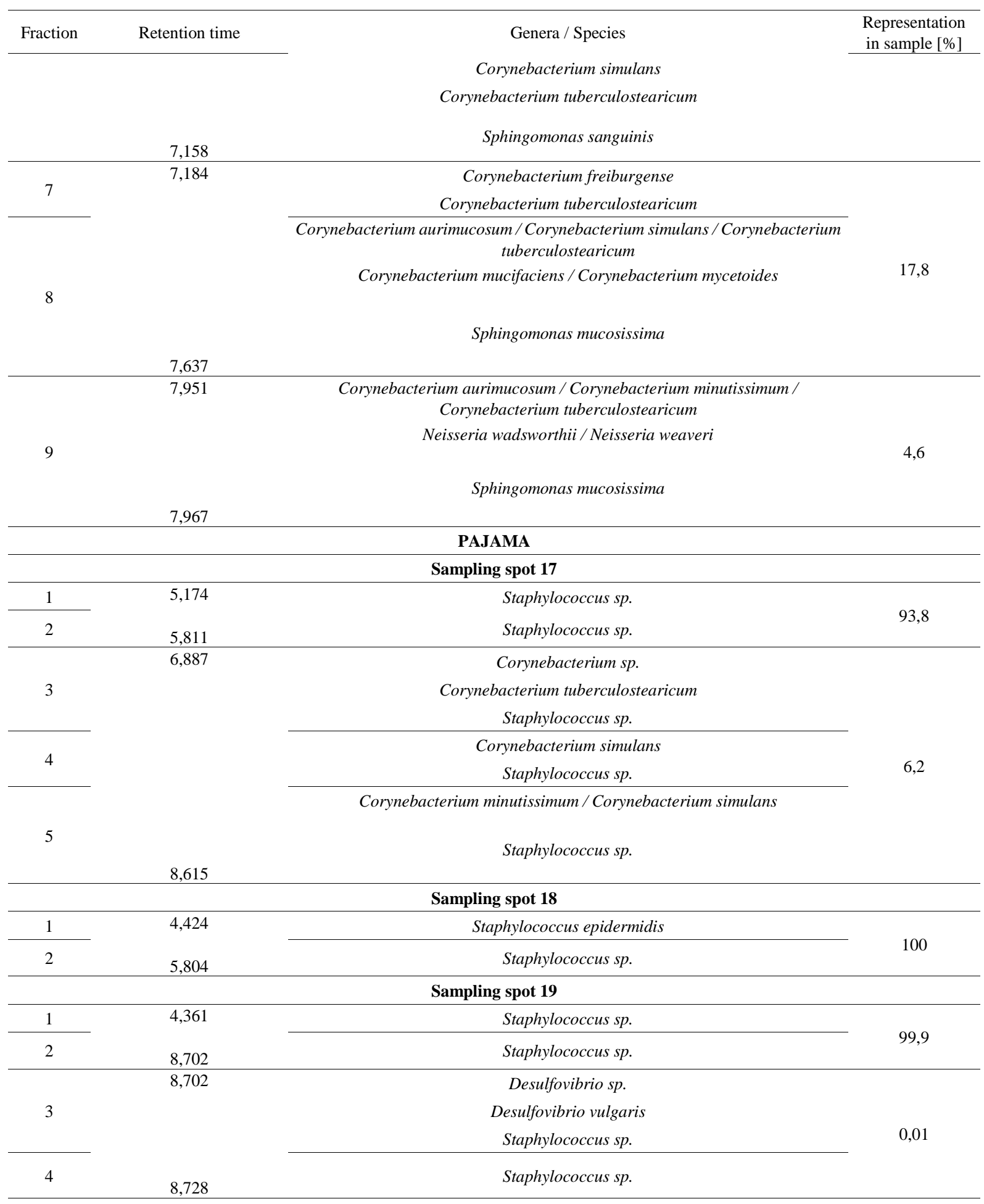

\section{REFERENCES}

[1] Poza M, Gayoso C, Gómez MJ, Rumbo-Feal S, Tomas M, Aranda J, et al. Exploring Bacterial Diversity in Hospital Environments by GS-FLX Titanium Pyrosequencing. PLoS One. 2012; 7(8).

[2] Arundel A V, Sterling EM, Biggin JH, Sterling TD. Indirect health effects of relative humidity in indoor environments. Environ Health Perspect [Internet]. National Institute of Environmental Health Science; 1986 Mar [cited 2016 Oct 7]; 65: 351-61. Available from: http://www.ncbi.nlm.nih.gov/pubmed/3709462

[3] Kembel SW, Jones E, Kline J, Northcutt D, Stenson J, Womack AM, et al. Architectural design influences the diversity and structure of the built environment microbiome. ISME J [Internet]. Nature Publishing Group; 2012 Aug 26 
[cited 2016 Oct 7]; 6(8):1469-79. Available from: http://www.nature.com/doifinder/10.1038/ismej.2011.211

[4] Neely AN. A survey of gram-negative bacteria survival on hospital fabrics and plastics. J Burn Care Rehabil [Internet]. 2000 [cited 2016 Oct 7]; 21(6):523-7. Available from: http://www.ncbi.nlm.nih.gov/pubmed/11194806

[5] Borkow G, Gabbay J. Biocidal textiles can help fight nosocomial infections. Med Hypotheses [Internet]. 2008 [cited 2016 Oct 7]; 70(5):990-4. Available from: http://www.ncbi.nlm.nih.gov/pubmed/17959322

[6] Weber DJ, Raasch R, Rutala WA. Nosocomial infections in the ICU: the growing importance of antibiotic-resistant pathogens. Chest [Internet]. 1999 Mar [cited 2016 Oct 7]; 115 (3 Suppl):34S-41S. Available from: http://www.ncbi.nlm.nih.gov/pubmed/10084458

[7] Plowman R, Great Britain. Public Health Laboratory Service. The socio-economic burden of hospital acquired infection: executive summary. Public Health Laboratory Service; 1999. $12 \mathrm{p}$.

[8] Vincent JL, Bihari DJ, Suter PM, Bruining HA, White J, Nicolas-Chanoin $\mathrm{MH}$, et al. The prevalence of nosocomial infection in intensive care units in Europe. Results of the European Prevalence of Infection in Intensive Care (EPIC) Study. EPIC International Advisory Committee. JAMA [Internet]. 1995 [cited 2016 Oct 7]; 274(8):639-44. Available from:

http://www.ncbi.nlm.nih.gov/pubmed/7637145

[9] Allegranzi B, Nejad BS, Garcia Castillejos G, Kilpatrick Claire, Kelley E, Mathai E. Report on the burden of endemic health care-associated infection worldwide. [Internet]. 2011. Available

from:http://apps.who.int/iris/bitstream/10665/80135/1/9789 241501507_eng.pdf

[10] Davies J, Davies D. Origins and evolution of antibiotic resistance. Microbiol Mol Biol Rev [Internet]. American Society for

Microbiology (ASM); 2010 Sep [cited 2016 Oct 7]; 74(3):417-3 http://www.ncbi.nlm.nih.gov/pubmed/20805405

[11] Nocker A, Burr M, Camper AK. Genotypic microbial community profiling: a critical technical review. Microb Ecol [Internet]. 2007 Aug [cited 2016 Jun 30]; 54(2):276-89. Available from:

http://www.ncbi.nlm.nih.gov/pubmed/17345133

[12] Handelsman J. Metagenomics: application of genomics to uncultured microorganisms. Microbiol Mol Biol Rev [Internet]. 2004 Dec [cited 2016 Oct 7]; 68(4):669-85. Available from:

http://www.ncbi.nlm.nih.gov/pubmed/15590779

[13] Head IM, Saunders JR, Pickup RW. Microbial Evolution, Diversity, and Ecology: A Decade of Ribosomal RNA Analysis of Uncultivated Microorganisms. Microb Ecol [Internet]. Springer-Verlag; 1998 Jan 1 [cited 2016 Oct 7]; 35(1):1-21. Available from: http://link.springer.com/10.1007/s002489900056

[14] Malik A, Masood F, Grohmann E. Management of Microbial Resources in the Environment: A Broad Perspective. In: Management of Microbial Resources in the Environment [Internet]. Dordrecht: Springer Netherlands; 2013 [cited 2016 Oct 7]. p. 1-15. Available from: http://link.springer.com/10.1007/978-94-007-5931-2_1

[15] Schleifer K-H. Microbial diversity: facts, problems and prospects. Syst Appl Microbiol [Internet]. 2004 Feb [cited 2016 Oct 7]; 27(1):3-9. Available from:

http://www.ncbi.nlm.nih.gov/pubmed/15053315

[16] Staley JT, Konopka A. Measurement of in situ activities of nonphotosynthetic microorganisms in aquatic and terrestrial habitats. Annu Rev Microbiol [Internet]. 1985 [cited 2016 Oct 7]; 39:321-46. Available from: http://www.ncbi.nlm.ni h.gov/pubmed/3904603

[17] Oberauner L, Zachow C, Lackner S, Högenauer C, Smolle $\mathrm{K}-\mathrm{H}$, Berg G. The ignored diversity: complex bacterial communities in intensive care units revealed by $16 \mathrm{~S}$ pyrosequencing. Sci Rep [Internet]. 2013; 3: 1413. Available from:

http://www.pubmedcentral.nih.gov/articlerender.fcgi?artid= 3593336\&tool=pmcentrez\&rendertype $=$ abstract

[18] Mátyás G, De Paepe A, Halliday D, Boileau C, Pals G, Steinmann B. Evaluation and application of denaturing HPLC for mutation detection in Marfan syndrome: Identification of 20 novel mutations and two novel polymorphisms in the FBN1 gene. Hum Mutat [Internet]. 2002 Apr [cited 2016 Oct 7]; 19(4):443-56. Available from: http://www.ncbi.nlm.nih.gov/pubmed/11933199

[19] Narayanaswami G, Taylor PD. Improved Efficiency of Mutation Detection by Denaturing High-Performance Liquid Chromatography Using Modified Primers and Hybridization Procedure. Genet Test [Internet].Mary Ann Liebert, Inc.; 2001 Mar [cited 2016 Oct 7]; 5(1):9-16. Available from: http://www.liebertonline.com/doi/abs/10.1 089/109065701750168608

[20] Wagner T, Stoppa-Lyonnet D, Fleischmann E, Muhr D, Pagès $S$, Sandberg $T$, et al. Denaturing high-performance liquid chromatography detects reliably BRCA1 and BRCA2 mutations. Genomics [Internet]. 1999 Dec 15 [cited 2016 Oct 7]; 62(3):369-76. Available from: http://www.ncbi.nlm.nih.gov/pubmed/10644434

[21] Xiao W, Oefner PJ. Denaturing high-performance liquid chromatography: A review. Hum Mutat [Internet]. 2001 Jun [cited 2016 Oct 7]; 17(6):439-74. Available from: http://www.ncbi.nlm.nih.gov/pubmed/11385705

[22] Barlaan EA, Sugimori M, Furukawa S, Takeuchi K. Profiling and monitoring of microbial populations by denaturing high-performance liquid chromatography. J Microbiol Methods [Internet]. 2005 Jun [cited 2016 Oct 7]; 61(3):399-412. Available from: http://www.ncbi.nlm.nih.g ov/pubmed/15767016

[23] Rabuza U, Sostar-Turk S, Fijan S. Efficiency of four sampling methods used to detect two common nosocomial pathogens on textiles. Text Res J [Internet]. 2012; 82(20):2099-105. Available from:http://www.scopus.com/i nward/record.url?eid=2-s2.0-84870454258\&partnerID=tZO tx3y1

[24] Domann E, Hong G, Imirzalioglu C, Turschner S, Kühle J, Watzel C, et al. Culture-independent identification of pathogenic bacteria and polymicrobial infections in the genitourinary tract of renal transplant recipients. J Clin Microbiol [Internet]. 2003 Dec [cited 2016 Oct 7]; 41(12):5500-10. Available from: http://www.ncbi.nlm.nih. gov/pubmed/14662931 
[25] Thompson JR, Marcelino LA, Polz MF. Heteroduplexes in mixed-template amplifications: formation, consequence and elimination by "reconditioning PCR". Nucleic Acids Res [Internet]. Oxford University Press; 2002 May 1 [cited 2016 Oct 7]; 30(9):2083-8. Available from: http://www.ncbi.nlm .nih.gov/pubmed/11972349

[26] Wagner AO, Malin C, Illmer P. Application of denaturing high-performance liquid chromatography in microbial ecology: fermentor sludge, compost, and soil community profiling. Appl Environ Microbiol [Internet]. American Society for Microbiology; 2009 Feb [cited 2016 Oct 10]; 75(4):956-64. Available from: http://www.ncbi.nlm.nih.go v/pubmed/19088311

[27] ter Brakk CJF, Šmilauer P. CANOCO reference manual and CanoDraw for Windows user's guide: software for canonical community ordination (version 4.5) | Clc [Internet]. Ithaca NY: Microcomputer Power; 2002. 500p p. Available from: http://library.wur.nl/WebQuery/clc/172250 0

[28] Costello EK, Lauber CL, Hamady M, Fierer N, Gordon JI, Knight R. Bacterial Community Variation in Human Body Habitats Across Space and Time. Science (80- ). 2009; 326(5960).

[29] Qin J, Li R, Raes J, Arumugam M, Burgdorf KS, Manichanh $\mathrm{C}$, et al. A human gut microbial gene catalogue established by metagenomic sequencing. Nature [Internet]. Nature Publishing Group; 2010 Mar 4 [cited 2016 Oct 7]; 464(7285):59-65. Available from:http://www.nature.com/d oifinder/10.1038/nature08821

[30] Zaura E, Keijser BJ, Huse SM, Crielaard W, Turnbaugh P, Hamady $M$, et al. Defining the healthy \&quot;core microbiome\&quot; of oral microbial communities. BMC Microbiol [Internet]. BioMed Central; 2009 [cited 2016 Oct 7]; 9(1):259. Available from: http://bmcmicrobiol.biomedce ntral.com/articles/10.1186/1471-2180-9-259

[31] Angelakis E, Roux V, Raoult D. Sphingomonas mucosissima Bacteremia in patient with sickle cell disease. Emerg Infect Dis [Internet]. Centers for Disease Control and Prevention; 2009 Jan [cited 2016 Oct 7]; 15(1):133-4. Available from: http://www.ncbi.nlm.nih.gov/pubmed/1911 6079

[32] Gai Z, Wang X, Liu X, Tai C, Tang H, He X, et al. The genes coding for the conversion of carbazole to catechol are flanked by IS6100 elements in Sphingomonas sp. strain XLDN2-5. PLoS One [Internet]. 2010 [cited 2016 Oct 7]; 5(4):e10018. Available from: http://www.ncbi.nlm.nih.gov/ pubmed/20368802

[33] Wang J-L, Chen M-L, Lin YE, Chang S-C, Chen Y-C. Association between contaminated faucets and colonization or infection by nonfermenting gram-negative bacteria in intensive care units in Taiwan. J Clin Microbiol [Internet]. American Society for Microbiology; 2009 Oct [cited 2016 Oct 7]; 47(10):3226-30. Available from: http://www.ncbi.nlm.nih.gov/pubmed/19587299

[34] Bulut C, Yetkin MA, Koruk ST, Erdinç FS, Karakoç EA. [A rare cause of nosocomial bacteremia: Sphingomonas paucimobilis]. Mikrobiyoloji bülteni [Internet]. 2008 Oct [cited 2016 Oct 7]; 42(4):685-8. Available from: http://www.ncbi.nlm.nih.gov/pubmed/19149092

[35] Denton M, Kerr KG. Microbiological and clinical aspects of infection associated with Stenotrophomonas maltophilia Clin Microbiol Rev [Internet]. 1998 Jan [cited 2016 Oct 7]; 11(1):57-80. Available from: http://www.ncbi.nlm.nih.gov/ pubmed/9457429

[36] Collins MD, Hoyles L, Hutson RA, Foster G, Falsen E. Corynebacterium testudinoris sp. nov., from a tortoise, and Corynebacterium felinum sp. nov., from a Scottish wild cat. Int J Syst Evol Microbiol [Internet]. 2001 Jul [cited 2016 Oct 7];51(Pt 4):1349-52. Available from: http://www.ncbi.nlm. nih.gov/pubmed/11491332

[37] Carey RB, Banerjee SN, Srinivasan A. Multidrug-resistant Acinetobacter infections, 1995-2004. In: 46th Interscience Conference on Antimicrobial Agents and Chemotherapy. 2006.

[38] Munoz-Price LS, Weinstein RA. Acinetobacter Infection. N Engl J Med [Internet].Massachusetts Medical Society; 2008 Mar 20 [cited 2016 Oct 7]; 358(12):1271-81. Available from:http://www.nejm.org/doi/abs/10.1056/NEJMra070741

[39] Rice LB. Challenges in identifying new antimicrobial agents effective for treating infections with Acinetobacter baumannii and Pseudomonas aeruginosa. Clin Infect Dis [Internet]. 2006 Sep 1 [cited 2016 Oct 7]; 43 Suppl 2:S100-5. Available from: http://www.ncbi.nlm.nih.gov/pubmed/1689 4511

[40] Lowy FD. Staphylococcus aureus Infections. N Engl J Med [Internet].Massachusetts Medical Society; 1998 Aug 20 [cited 2016 Oct 7]; 339(8):520-32. Available from: http://www.nejm.org/doi/abs/10.1056/NEJM199808203390 806

[41] Hanberger H, Walther S, Leone M, Barie PS, Rello J, Lipman J, et al. Increased mortality associated with methicillin-resistant Staphylococcus aureus (MRSA) infection in the intensive care unit: results from the EPIC II study. Int J Antimicrob Agents [Internet]. 2011 Oct [cited 2016 Oct 7]; 38(4):331-5. Available from: http://www.ncbi.nlm.nih.gov/pubmed/21798720

[42] Guthrie JL, Robertson A V, Tang P, Jamieson F, Drews SJ. Novel duplex real-time PCR assay detects Bordetella holmesii in specimens from patients with Pertussis-like symptoms in Ontario, Canada. J Clin Microbiol [Internet]. American Society for Microbiology; 2010 Apr [cited 2016 Oct 7]; 48(4):1435-7. Available from: http://www.ncbi.nlm .nih.gov/pubmed/20181919

[43] Sihvonen LM, Jalkanen K, Huovinen E, Toivonen S, Corander J, Kuusi M, et al. Clinical isolates of Yersinia enterocolitica biotype 1A represent two phylogenetic lineages with differing pathogenicity-related properties. BMC Microbiol [Internet]. 2012 [cited 2016 Oct 7]; 12:208. Available from: http://www.ncbi.nlm.nih.gov/pubmed/2298 5268

[44] Centers for Disease Control and Prevention (CDC). Pseudomonas dermatitis/folliculitis associated with pools and hot tubs--Colorado and Maine, 1999-2000. MMWR Morb Mortal Wkly Rep [Internet]. 2000 Dec 8 [cited 2016 Oct 7];49(48):1087-91. Available from: http://www.ncbi.nl m.nih.gov/pubmed/11130858

[45] Favero MS, Carson LA, Bond WW, Petersen NJ. Pseudomonas aeruginosa: Growth in Distilled Water from Hospitals. Science (80- ). 1971; 173(3999). 
[46] Kennedy AM, Elward AM, Fraser VJ. Survey of knowledge, beliefs, and practices of neonatal intensive care unit healthcare workers regarding nosocomial infections, central venous catheter care, and hand hygiene. Infect Control Hosp Epidemiol [Internet]. 2004 Sep [cited 2016 Oct 7]; 25(9):747-52. Available from: http://www.ncbi.nlm.nih.go v/pubmed/15484799

[47] van Elsas JD, Chiurazzi M, Mallon CA, Elhottova D, Kristufek V, Salles JF. Microbial diversity determines the invasion of soil by a bacterial pathogen. Proc Natl Acad Sci U S A [Internet]. National Academy of Sciences; 2012 Jan 24 [cited 2016 Oct 7]; 109(4):1159-64. Available from: http://www.ncbi.nlm.nih.gov/pubmed/22232669
[48] Skraban J, Dzeroski S, Zenko B, Mongus D, Gangl S, Rupnik M, et al. Gut Microbiota Patterns Associated with Colonization of Different Clostridium difficile Ribotypes. Popoff MR, editor. PLoS One [Internet]. Public Library of Science; 2013 Feb 28 [cited 2016 Oct 10]; 8(2):e58005. Available from:http://dx.plos.org/10.1371/journal.pone.005 8005

[49] Goldenberg O, Herrmann S, Marjoram G, Noyer-Weidner M, Hong G, Bereswill S, et al. Molecular monitoring of the intestinal flora by denaturing high performance liquid chromatography. J Microbiol Methods [Internet]. 2007 Jan [cited 2016 Oct 10]; 68(1):94-105. Available from: http://www.ncbi.nlm.nih.gov/pubmed/16904779 